\title{
STACJE BAZOWE TELEFONII KOMÓRKOWEJ JAKO PRZEDSIĘWZIĘCIA MOGĄCE ZNACZĄCO ODDZIAEYWAĆ NA ŚRODOWISKO
}

\section{MOBILE PHONE BASE STATIONS AS PROJECTS "WHICH ARE LIKELY TO HAVE SIGNIFICANT EFFECTS ON THE ENVIRONMENT"}

\section{STRESZCZENIE W JĘZYKU POLSKIM}

W ostatnich latach w Polsce intensywnie rozwija się sieć telefonii komórkowej. Nadajniki tej telefonii emitują pole elektromagnetyczne, stąd inwestycje związane z ich lokalizacją i realizacją wymagają odpowiedniego zakwalifikowania ze względu na oddziaływanie na środowi-

* Magister prawa, asystent w Wojewódzkim Sądzie Administracyjnym w Poznaniu. 
sko. Orzecznictwo sądów administracyjnych ukazuje, iż istnieje wiele problemów w zakresie interpretacji i stosowania polskich przepisów określających kryteria zaliczenia instalacji emitujących pola elektromagnetyczne do grupy „przedsięwzięć mogących znacząco oddziaływać na środowisko". Zainspirowało to autora artykułu do dokonania przeglądu tych regulacji szczegółowych, analizy oraz oceny ich zmian i wreszcie - przedstawienia węzłowych problemów interpretacyjnych. Artykuł ukazuje złożoność problematyki związanej z kwalifikowaniem instalacji radiokomunikacyjnych do przeprowadzenia postępowania w sprawie oceny środowiskowej. Opracowanie podjętego tematu może okazać się przydatne tym bardziej, że przepisy szczegółowe określające kryteria zaliczania przedsięwzięć do kategorii „przedsięwzięć mogących znacząco oddziaływać na środowisko" wymagają wykładni. Wyniki tej wykładni - jak pokazują przykłady zawarte w artykule - mogą decydować o nałożeniu na inwestora stacji bazowych telefonii komórkowych obowiązku przeprowadzenia postępowania w sprawie oceny środowiskowej bądź o zwolnieniu go z niego.

\section{Słowa kluczowe w języku polskim}

Przedsięwzięcia mogące znacząco oddziaływać na środowisko, decyzja o środowiskowych uwarunkowaniach, stacje bazowe telefonii komórkowej.

\section{STRESZCZENIE W JĘZYKU ANGIELSKIM}

The mobile phone network has been developing intensively in Poland in recent years. Due to the fact that transmitters of this telephony emit the electromagnetic field any investment connected with their localization and realization requires the right classification because of its effects on the environment. The jurisprudence of administrative courts indicates that there are many problems with the interpretation and application of Polish provisions which determine the criteria of classifying the emitting electromagnetic field installations to the group of "projects which may significantly affect the environment". The above gave the author of the article the idea to review these detailed regulations, conduct their analysis, do evaluation of amendments and - finally - present the crucial interpretation problems. The article is on the complexity of issues connected with classification of radio 
communication installations which are relevant in the environment evaluation proceedings. The studies of the above subject may appear useful and what's more the detailed provisions, determining criteria of classifying projects to category of "projects which may significantly affect the environment", require the interpretation. The results of this interpretation - as it can be seen from the examples in the article may decide about imposing on the investor of base transceiver station an obligation to conduct proceedings on environment evaluation or exempting him from such an obligation.

\section{Słowa kluczowe w języku angielskim}

Projects which may significantly affect the environment, proceedings on environment evaluation, mobile phone base stations.

\section{PODDANIE OCENIE ŚRODOWISKOWEJ PLANOWANYCH INWESTYCJI STACJI BAZOWYCH TELEFONII KOMÓRKOWYCH - UWAGI WSTĘPNE}

W sprawach ocen środowiskowych sądownictwo administracyjne staje coraz częściej przed wyzwaniem rozstrzygnięcia zagadnień dotyczących specjalistycznych regulacji prawnych odnoszących się do konkretnych rodzajów inwestycji. Następuje to za sprawą zarzutów stron oraz uczestniczących w postępowaniach profesjonalnych organizacji ekologicznych posiadających niekiedy dużą wiedzę na temat oceny skali oraz skutków oddziaływania na środowisko kwestionowanych przez nie przedsięwzięć. Coraz bogatsze orzecznictwo dotyczące problematyki szczegółowej odnoszącej się do poszczególnych rodzajów instalacji lub urządzeń ujawnia ciekawe, ale i niekiedy skomplikowane zagadnienia prawne, jakie wiążą się z udzielaniem zezwoleń na ich lokalizację lub realizację. Inspiruje to do podjęcia wnikliwszej analizy prawnej przepisów warunkujących obowiązek przeprowadzenia ocen środowiskowych, tym bardziej, że właściwe odczytanie wielu z tych uregulowań okazuje się w praktyce bardzo trudne.

W niniejszym artykule autor koncentruje się na problematyce przesłanek poddania ocenie środowiskowej planowanych 
inwestycji stacji bazowych telefonii komórkowych. Wybór akurat tego rodzaju przedsięwzięć jest nieprzypadkowy. Wynika to z faktu, że regulacje prawne określające obowiązki inwestora w sytuacji ubiegania się o zezwolenie na lokalizację lub realizację stacji bazowych telefonii komórkowych budzą wiele poważnych kontrowersji i sporów - zwłaszcza gdy chodzi o kwestię ich oddziaływania na środowisko. Problematyka ta jest warta uwagi także w tego powodu, że w dobie rozwoju sieci telefonii mobilnej tego rodzaju inwestycji realizuje się bardzo dużo i to często w warunkach mogących powodować uzasadniony sprzeciw ze strony społeczeństwa (m.in. obszarach zamieszkania).

W pierwszej kolejności należy wyjaśnić, że stacje bazowe telefonii komórkowych należą do grupy urządzeń emitujących pola elektromagnetyczne, przez co rozumie się pole elektryczne, magnetyczne oraz elektromagnetyczne o częstotliwościach od $0 \mathrm{~Hz}$ do $300 \mathrm{GHz}$ (art. 3 pkt 18 ustawy z dnia 27 kwietnia 2001 r. Prawo ochrony środowiska ${ }^{1}$ ). Ich oddziaływania nie traktuje się jako niebezpiecznego dla ludzi pod warunkiem zachowania podstawowych wymogów określonych w przepisach ustawy oraz w przepisach wykonawczych. Zgodnie z art. 121 pkt 1 i 2 P.o.ś. ochrona przed polami elektromagnetycznymi polega na zapewnieniu jak najlepszego stanu środowiska poprzez: utrzymanie poziomów pól elektromagnetycznych poniżej dopuszczalnych lub co najmniej na tych poziomach oraz poprzez zmniejszanie poziomów pól elektromagnetycznych co najmniej do dopuszczalnych, gdy nie są one dotrzymane. Dopuszczalne poziomy pól elektromagnetycznych w środowisku określone zostały w rozporządzeniu z dnia 30 października 2003 r. w sprawie dopuszczalnych poziomów pól elektromagnetycznych w środowisku oraz sposobów sprawdzania dotrzymania tych poziomów ${ }^{2}$, którym zastąpiono dotychczasowe rozporządzenie Ministra Ochrony Środowiska, Zasobów Naturalnych i Leśnictwa z dnia 11 sierpnia 1998 r. w sprawie szczegółowych zasad ochrony przed promieniowaniem szkodliwym dla ludzi i środowiska, dopuszczalnych poziomów promieniowania, jakie mogą występować w środowisku,

2 Dz.U. Nr 92, poz. 1883. 
oraz wymagań obowiązujących przy wykonywaniu pomiarów kontrolnych promieniowania ${ }^{3}$. Dla pól elektromagnetycznych o częstotliwościach powyżej $300 \mathrm{MHz}$ (megaherców) - częstotliwościach wykorzystywanych w telefonii komórkowej ${ }^{4}$ - standard jakości środowiska określony jako dopuszczalny poziom składowej elektrycznej dla pola elektromagnetycznego w miejscach dostępnych dla ludności wynosi $7 \mathrm{~V} / \mathrm{m}$. Dla pola elektromagnetycznego o częstotliwości powyżej $300 \mathrm{MHz}$, jako standardu jakości środowiska, używa się także współczynnika gęstości mocy pola, który wynosi $0,1 \mathrm{~W} / \mathrm{m}^{2}$. Wskazane wyżej krajowe regulacje uważa się za określające poziom ochrony na dostatecznym poziomie, a także spełniającym normy określone w uznawanej ${ }^{5}$ przez instytucje Unii Europejskiej rekomendacji Rady z dnia 12 lipca 1999 r. 1999/519/WE dotyczącej ograniczenia ekspozycji ogółu ludności na promieniowanie elektromagnetyczne ${ }^{6}$.

Wyżej wymienionych współczynników autor artykułu nie czyni przedmiotem analizy. Ich przytoczenie ma na celu jedynie wskazanie, że pola elektromagnetyczne powinny spełniać standardy określone prawem.

Od przepisów określających dopuszczalne poziomy promieniowania elektroenergetycznego, jakie stacja bazowa może emitować, należy wyraźnie odróżnić regulacje stanowiące gwarancje zachowania dopuszczalnych norm emisji. Te drugie można podzielić na dwie grupy:

a) służące zapobieganiu powstawaniu nadmiernej emisji pola elektromagnetycznego z planowanego przedsięwzięcia -

3 Dz.U. Nr 107, poz. 676.

4 Stanowisko Komisji Higieny Radiacyjnej Rady Sanitarno - Epidemiologicznej przy Głównym Inspektorze Sanitarnym z dnia 9 października 2007 r. w sprawie potencjalnej szkodliwości pól elektromagnetycznych (PEM) emitowanych przez urządzenia bazowe telefonii komórkowej, publ. na stronach internetowych Ministerstwa Środowiska: http://www.mos.gov.pl.

5 Zob. art. 4 ust. 3 dyrektywy Parlamentu Europejskiego i Rady z dnia 29 kwietnia 2004 r. 2004/40/WE w sprawie minimalnych wymagań w zakresie ochrony zdrowia i bezpieczeństwa dotyczących narażenia pracowników na ryzyko spowodowane czynnikami fizycznymi (polami elektromagnetycznymi) (osiemnasta dyrektywa szczegółowa w rozumieniu art. 16 ust. 1 dyrektywy 89/391/EWG) - Dz. Urz. UE L 159 z 30.04.2004, s. 1-26.

6 Dz. Urz. UE L 199 z 30.7.1999, s. 59-70. 
do tej grupy należą przepisy dotyczące postępowań w sprawach środowiskowych uwarunkowań;

b) dotyczące przeciwdziałania naruszeniom dopuszczalnych poziomów emisji i ich kontroli - a więc regulacje nakładające na prowadzących i użytkowników instalacji lub urządzeń powodujących emisję pola elektromagnetycznego obowiązek dokonywania pomiarów poziomu pól w środowisku (zob. art. 122a P.o.ś. i wyżej powołane rozporządzenie z dnia 30 października 2003 r. w sprawie dopuszczalnych poziomów pól elektromagnetycznych w środowisku oraz sposobów sprawdzania dotrzymania tych poziomów). W przypadku stacji bazowych telefonii komórkowych szczególnie ważną rolę odgrywają przepisy dotyczące zapobiegania nadmiernej emisji, a więc dotyczące wdrożenia postępowania w sprawie warunków środowiskowych inwestycji. Mają one na celu stworzenie gwarancji - zgodnie z zasadą przezorności - by już na etapie przygotowania przedsięwzięcie było projektowane w sposób najmniej uciążliwy dla środowiska, a przynajmniej, by nie mogło oddziaływać na środowisko w sposób nadmierny.

Nałożenie na inwestorów stacji bazowych telefonii komórkowych warunku uprzedniego przeprowadzenia postępowania w sprawie ich oddziaływania na środowisko wiązało się z koniecznością przyjęcia określonych kryteriów kwalifikujących zaliczenie tych przedsięwzięć do kategorii przedsięwzięć mogących znacząco oddziaływać na środowisko (a wcześniej: do kategorii przedsięwzięć wymagających albo mogących wymagać sporządzenia raportu o oddziaływaniu na środowisko).

W polskim systemie prawnym już dość dawno zdecydowano się włączyć stacje bazowe telefonii komórkowej do katalogu przedsięwzięć wymagających oceny oddziaływania przedsięwzięcia na środowisko albo co do których przeprowadzenie takiej oceny może być wymagane. Uczyniono to pomimo braku takiego obowiązku wynikającego z przepisów dyrektywy 85/337/EWG z dnia 27 czerwca 1985 r. w sprawie oceny skutków wywieranych przez niektóre przedsięwzięcia publiczne i prywatne na środowisko naturalne ${ }^{7}$, którą uwzględniano w pracach nad 
przygotowaniem Prawa ochrony środowiska ${ }^{8}$. Przez włączenie instalacji i urządzeń emitujących pole elektromagnetyczne do grupy przedsięwzięć wymagających przeprowadzenia postępowania w sprawie środowiskowych uwarunkowań prawodawca krajowy niejako dobrowolnie poddał je rozwiązaniom wprowadzonym w efekcie implementacji norm prawa unijnego. Tym samym wskazana dyrektywa rzutuje na sposób oceny inwestycji stacji bazowych telefonii komórkowych.

Ustawa z dnia 27 kwietnia 2001 r. Prawo ochrony środowiska $\mathrm{w}$ jej pierwotnym brzmieniu ${ }^{9}$ przewidywała, iż ocena oddziaływania przedsięwzięć na środowisko następować będzie w ramach postępowania zmierzającego do wydania decyzji udzielającej zgodę na realizację inwestycji (art. 46 ust. 1 i 3 ustawy, por. art. 2 ust. 2 dyrektywy 85/337/EWG). Inwestor zamierzający zrealizować przedsięwzięcie wymagające oceny oddziaływania na środowisko obowiązany był przedłożyć raport o takim oddziaływaniu. Planowane przedsięwzięcia mogące znacząco oddziaływać na środowisko zawsze wymagające raportu oraz przedsięwzięcia, dla których obowiązek przedłożenia raportu powinien być stwierdzony wymienione zostały w rozporządzeniu Rady Ministrów z dnia 24 września 2002 r. w sprawie określenia rodzajów przedsięwzięć mogących znacząco oddziaływać na środowisko oraz szczegółowych kryteriów związanych z kwalifikowaniem przedsięwzięć do sporządzenia raportu o oddziaływaniu na środowisko ${ }^{10}$ wydanym na podstawie art. 51 ust. 8 P.o.ś. Zgodnie z § 2 pkt 9 lit. g tego rozporządzenia sporządzenia raportu o oddziaływaniu przedsięwzięcia na środowisko wymagały instalacje radiokomunikacyjne, radionawigacyjne i radiolokacyjne, emitujące pola elektromagnetyczne, których równoważna moc promieniowana izotropowo wynosi nie mniej niż $100 \mathrm{~W}$, emitujące pola elektromagnetyczne o częstotliwościach od $30 \mathrm{kHz}$ do $300 \mathrm{GHz}$, natomiast w myśl § 3 pkt 12 lit. o sporządzenia raportu mogły wymagać instalacje radiokomu-

8 Zob. uzasadnienie projektu ustawy opublikowane na stronach: www. sejm.gov.pl, przy Druku Sejmowym Sejmu III Kadencji nr 1856.

9 Dz. U. z 2001 r. Nr 62, 627.

10 Dz. U. Nr 179, poz. 1490 ze zm. 
nikacyjne, radionawigacyjne i radiolokacyjne, emitujące pola elektromagnetyczne, których równoważna moc promieniowana izotropowo wynosi nie mniej niż $15 \mathrm{~W}$, emitujące pola elektromagnetyczne o częstotliwościach od $30 \mathrm{kHz}$ do $300 \mathrm{GHz}$, niewymienione w $\S 2$ ust. 1 pkt 9 lit. g. Omawiane wyżej rozporządzenie zastąpiono rozporządzeniem Rady Ministrów z dnia 9 listopada 2004 r. w sprawie określenia rodzajów przedsięwzięć mogących znacząco oddziaływać na środowisko oraz szczegółowych uwarunkowań związanych z kwalifikowaniem przedsięwzięcia do sporządzenia raportu o oddziaływaniu na środowisko ${ }^{11}$. W pierwotnej wersji tego aktu identyczne regulacje znalazły się odpowiednio w $\S 2$ ust. 1 pkt 7 (instalacje wymagające sporządzenia raportu) oraz w $\S 3$ ust. 1 pkt 8 (instalacje, które mogą wymagać sporządzenia raportu).

Kryteria wyżej opisanych rozporządzeń należały do najbardziej restrykcyjnych, jakie obowiązywały dotąd w odniesieniu do inwestycji stacji bazowych telefonii komórkowych. Można bowiem przyjąć, że na podstawie tych aktów większość instalacji i urządzeń wymagała sporządzenia raportu o oddziaływaniu przedsięwzięcia na środowisko. Analiza orzecznictwa sądów administracyjnych wskazuje, że w okresie przed 2007 r. w znacznej części spraw przedmiotem sporów było nie tyle to czy dana stacja bazowa jest przedsięwzięciem wymagającym oceny oddziaływania na środowisko (sporządzenia raportu), ale to czy ocena ta została przeprowadzona w sposób obiektywny ${ }^{12}$.

11 Dz. U. z 2004 r. Nr 257, poz. 2573.

12 Zob. przykładowo: wyrok z dnia 12 kwietnia 2006 r. sygn. akt II OSK 721/05, niepubl. oraz wyrok z dnia 22 marca 2006 r. sygn. akt IV SA/ Wa 1817/05, publ.: Centralna Baza Orzeczeń Sądów Administracyjnych, http://orzeczenia.nsa.gov.pl. 


\section{ZMIANA KRYTERIÓW WDROŻENIA POSTĘPOWANIA W SPRAWIE ŚRODOWISKOWYCH UWARUNKOWAŃ W ODNIESIENIU INSTALACJI RADIOKOMUNIKACYJNYCH}

W 2007 r. podjęto pierwsze kroki mające zliberalizować przepisy dotyczące kryteriów wdrożenia postępowania w sprawie środowiskowych uwarunkowań $\mathrm{w}$ odniesieniu instalacji radiokomunikacyjnych. Rozporządzeniem z dnia 21 sierpnia 2007 r. zmieniono rozporządzenie w sprawie określenia rodzajów przedsięwzięć mogących znacząco oddziaływać na środowisko oraz szczegółowych uwarunkowań związanych z kwalifikowaniem przedsięwzięcia do sporządzenia raportu o oddziaływaniu na środowisko ${ }^{13}$. W nowelizacji, zamiast jednego kryterium związanego z mocą instalacji, wprowadzono kilka poziomów równoważnej mocy promieniowanej izotropowo. Zgodnie z §2 ust. 1 pkt 7 znowelizowanego rozporządzenia sporządzenia raportu o oddziaływaniu przedsięwzięcia na środowisko wymagały instalacje radiokomunikacyjne, radionawigacyjne i radiolokacyjne, z wyłączeniem radiolinii, emitujące pola elektromagnetyczne o częstotliwościach od 0,03 MHz do $300000 \mathrm{MHz}$, w których równoważna moc promieniowana izotropowo wyznaczona dla pojedynczej anteny wynosi:

a) nie mniej niż $2000 \mathrm{~W}$, a miejsca dostępne dla ludności znajdują się w odległości nie większej niż 100 m od środka elektrycznego, wzdłuż osi głównej wiązki promieniowania tej anteny,

b) nie mniej niż $5000 \mathrm{~W}$, a miejsca dostępne dla ludności znajdują się w odległości nie większej niż 150 m od środka elektrycznego, wzdłuż osi głównej wiązki promieniowania tej anteny,

13 Rozporządzenie Rady Ministrów z dnia 21 sierpnia 2007 r. zmieniające rozporządzenie w sprawie określenia rodzajów przedsięwzięć mogących znacząco oddziaływać na środowisko oraz szczegółowych uwarunkowań związanych z kwalifikowaniem przedsięwzięcia do sporządzenia raportu o oddziaływaniu na środowisko, Dz.U. Nr 108, poz. 1105 ze zm. 
c) nie mniej niż $10000 \mathrm{~W}$, a miejsca dostępne dla ludności znajdują się w odległości nie większej niż 200 m od środka elektrycznego, wzdłuż osi głównej wiązki promieniowania tej anteny,

d) nie mniej niż $20000 \mathrm{~W}$;

natomiast sporządzenia raportu mogły wymagać instalacje radiokomunikacyjne, radionawigacyjne i radiolokacyjne, niewymienione w §2 ust. 1 pkt 7, z wyłączeniem radiolinii, emitujące pola elektromagnetyczne o częstotliwościach od $0,03 \mathrm{MHz}$ do $300.000 \mathrm{MHz}$, w których równoważna moc promieniowana izotropowo wyznaczona dla pojedynczej anteny wynosi:

a) nie mniej niż $15 \mathrm{~W}$, a miejsca dostępne dla ludności znajdują się w odległości nie większej niż 5 m od środka elektrycznego, wzdłuż osi głównej wiązki promieniowania tej anteny,

b) nie mniej niż $100 \mathrm{~W}$, a miejsca dostępne dla ludności znajdują się w odległości nie większej niż 20 m od środka elektrycznego, wzdłuż osi głównej wiązki promieniowania tej anteny,

c) nie mniej niż $500 \mathrm{~W}$, a miejsca dostępne dla ludności znajdują się w odległości nie większej niż 40 m od środka elektrycznego, wzdłuż osi głównej wiązki promieniowania tej anteny,

d) nie mniej niż $1000 \mathrm{~W}$, a miejsca dostępne dla ludności znajdują się w odległości nie większej niż 70 m od środka elektrycznego, wzdłuż osi głównej wiązki promieniowania tej anteny,

e) nie mniej niż $2000 \mathrm{~W}$, a miejsca dostępne dla ludności znajdują się w odległości nie większej niż $150 \mathrm{~m}$ i nie mniejszej niż 100 m od środka elektrycznego, wzdłuż osi głównej wiązki promieniowania tej anteny,

f) nie mniej niż $5000 \mathrm{~W}$, a miejsca dostępne dla ludności znajdują się w odległości nie większej niż 200 m i nie mniejszej niż 150 m od środka elektrycznego, wzdłuż osi głównej wiązki promieniowania tej anteny,

g) nie mniej niż $10000 \mathrm{~W}$, a miejsca dostępne dla ludności znajdują się w odległości nie większej niż 300 m i nie mniej- 
szej niż 200 m od środka elektrycznego, wzdłuż osi głównej wiązki promieniowania tej anteny.

Projekt powyższej nowelizacji powstał - jak podnoszono w jego uzasadnieniu - na bazie wieloletnich doświadczeń dotyczących instalacji telefonii komórkowej nabytych przez projektantów instalacji jak i administrację państwową ${ }^{14}$. W miejsce dotychczasowego, jednego kryterium kwalifikowania instalacji wytwarzających pola elektromagnetyczne o częstotliwościach radiowych - to jest równoważnej mocy promieniowanej izotropowo - wprowadzono kryterium podwójne, polegające na uzależnieniu kwalifikowania instalacji nie tylko w oparciu o poziom równoważnej mocy promieniowanej izotropowo, ale także w oparciu o odległość miejsc dostępnych dla ludności, określanej względem anten. Autorzy projektu nowelizacji wskazywali, że zmiana przepisów pozwala na lepsze uwzględnienie zjawisk zachodzących w otoczeniu instalacji emitujących pole elektromagnetyczne o częstotliwościach radiowych, gdyż rozkłady natężeń pól elektromagnetycznych $\mathrm{w}$ otoczeniu instalacji radiokomunikacyjnych zależą przede wszystkim od charakterystyk promieniowania anten wykorzystywanych w instalacjach oraz mocy doprowadzanych do anten. Podkreślano też, iż przyjęcie zaproponowanych rozwiązań nie obniży standardu ochrony przed oddziaływaniem pól elektromagnetycznych określonego przez dopuszczalne poziomy tych pól w środowisku w myśl rozporządzenia z dnia 30 października $2003 \mathrm{r}^{15}$

Nowelizacja z dnia 21 sierpnia 2007 r. wprowadziła istotne zmiany w postępowaniach dotyczących uwarunkowań środowiskowych dla stacji bazowych telefonii komórkowych. Dzięki wprowadzeniu kryterium odległości od środka elektrycznego znaczną część tego rodzaju postępowań umorzono, albowiem w odniesieniu do instalacji znajdujących się w przyjętych odległościach od miejsc dostępnych dla ludzi odpadła potrzeba wydania decyzji o środowiskowych uwarunkowaniach. Z kolei

14 Zob. uzasadnienie projektu rozporządzenia dostępne na witrynach internetowych Ministerstwa Środowiska: http://ww.mos.gov.pl/bip/pliki_do_ pobrania/070829_1513301593projekt_29.08.pdf.

15 Zob. wyżej. 
w przypadku znacznego odsetka nowych wniosków dotyczących decyzji na lokalizację albo realizację inwestycji stacji bazowych inwestorzy nie byli już obowiązani uzyskiwać decyzji o środowiskowych uwarunkowaniach zgody na realizację przedsięwzięcia.

Kryteria kwalifikowania instalacji radiokomunikacyjnych przyjęte $\mathrm{w}$ drodze nowelizacji z dnia 21 sierpnia $2007 \mathrm{r}$. obowiązywały w niezmienionym brzmieniu do 14 listopada 2010 r., to jest do dnia wejścia w życie rozporządzenia z dnia 9 listopada 2010 r. w sprawie przedsięwzięć mogących znacząco oddziaływać na środowisko ${ }^{16}$ wydanego na podstawie art. 60 ustawy z dnia 3 października 2008 r. o udostępnianiu informacji o środowisku i jego ochronie, udziale społeczeństwa w ochronie środowiska oraz o ocenach oddziaływania na środowisko ${ }^{17}$. W tym drugim rozporządzeniu kryteria kwalifikowania instalacji radiokomunikacyjnych zostały określone niemalże identycznie, z jedną tylko kontrowersyjną zmianą - która omówiona zostanie osobno w dalszej części artykułu.

Sposób określenia kryteriów kwalifikujących instalacje radiokomunikacyjne do grupy przedsięwzięć mogących znacząco oddziaływać na środowisko, wprowadzonych nowelizacją z dnia 21 sierpnia 2007 r. należy ocenić krytycznie. Celem liberalizacji tych przepisów dokonanej w 2007 r. było ułatwienie procesu inwestycyjnego w stosunku do tej części z nich, które z pewnością nie mogły powodować negatywnego oddziaływania na środowisko. $\mathrm{Z}$ takim założeniem trudno było się nie zgodzić, tym bardziej, że chodziło przyspieszenie rozbudowy elementów infrastruktury telekomunikacyjnej w Polsce. Teoretycznie trafne założenia, jakie legły u podstaw nowelizacji, nie mogły jednak przysłonić jej mankamentów.

W pierwszej kolejności należy poddać pod wątpliwość, czy wyłączenie szeregu inwestycji obejmujących stacje bazowe telefonii komórkowych od obowiązku przeprowadzenia postępowania w sprawie środowiskowych uwarunkowań daje się pogodzić z zasadą prewencji wyrażoną w art. 6 ust. 1 P.o.s. oraz zasadą

17 Dz. U. Nr 199, poz. 1227; dalej: ustawa o udostępnianiu informacji o środowisku. 
partycypacji publicznej wynikającą z art. 74 ust. 4 Konstytucji RP. Jak wskazano wyżej, do dnia 30 sierpnia 2007 r. obowiązywały kryteria nakazujące przeprowadzenie postępowania w sprawie środowiskowych uwarunkowań w odniesieniu do niemalże wszystkich stacji bazowych telefonii komórkowej. Rozwiązanie to powodowało, że realizację tych inwestycji poprzedzało przygotowanie przez inwestora specjalistycznego opracowania, pozwalającego właściwym organom już w fazie oceny projektu zorientować się, jakie zagrożenia niesie lub może nieść za sobą dana instalacja na skutek emisji pola elektromagnetycznego. Co więcej, organ mógł zapewnić udział w postępowaniu wszystkim osobom, których interes mógł być przez tę emisję zagrożony.

Zliberalizowane kryteria dotyczące ocen środowiskowych instalacji radiokomunikacyjnych wyłączyły natomiast możliwość wnikliwej oceny znacznej części z nich na etapie projektowania - zarówno przez organ, jak i zainteresowane społeczeństwo, a to z kolei nie sprzyjało zapobieganiu powstawania źródeł nadmiernego oddziaływania elektromagnetycznego. Odstępując od mechanizmów pozwalających zapobiegać powstawaniu instalacji mogących wywoływać niekorzystny wpływ na środowisko ograniczono istotnie możliwość realizacji zasady prewencji rozumianej jako „uwzględnianie wymogów ochrony jeszcze przed podjęciem działalności; stosowania metod i technologii dla środowiska najkorzystniejszych (przede wszystkim tzw. czystych technologii, wykluczających powstawanie lub poważnie zmniejszających zakres uciążliwości dla środowiska); przestrzegania zasad szczególnej ostrożności przy podejmowaniu działań o nieznanym wpływie na środowisko"18.

Zmieniając rozporządzenie w sprawie określenia rodzajów przedsięwzięć mogących znacząco oddziaływać na środowisko powoływano się - co prawda - na nieznacznie wcześniej znowelizowany art. $122 \mathrm{a}^{19}$ P.o.ś., w którym obowiązkiem wykonania

18 M. Górski, Ochrona środowiska jako zadanie administracji publicznej, Łódź 1992 r., s. 124.

19 Zob. uzasadnienie projektu rozporządzenia dostępne na witrynach internetowych Ministerstwa Środowiska: http://ww.mos.gov.pl/bip/pliki_do_ pobrania/070829_1513301593projekt_29.08.pdf. 
pomiarów poziomów pól elektromagnetycznych w środowisku objęto wszystkich prowadzących oraz użytkowników instalacji emitujących pola elektromagnetyczne o równoważnej mocy promieniowana izotropowo wynoszącej nie mniej niż $15 \mathrm{~W}$ i emitujących pola elektromagnetyczne o częstotliwościach od $30 \mathrm{kHz}$ do $300 \mathrm{GHz}$. Argument ten wydaje się jednak niewystarczający, tym bardziej, że badania, do których zobowiązany jest prowadzący i użytkownik takich instalacji dokonywane są następczo, po rozpoczęciu użytkowania instalacji lub urządzenia emitującego. Dodatkowo zauważyć trzeba, że kontrola nadmiernej emisji dokonywana w trybie art. 122a pkt 1 P.o.ś. nie jest dokonywana w ramach postępowania jurysdykcyjnego i nie zapewnia się w niej udziału społeczeństwa.

Zasada udziału społeczeństwa (partycypacji publicznej ${ }^{20}$ ) jest zresztą kolejną zasadą, którą wyraźnie ograniczono w odniesieniu do lokalizacji lub realizacji instalacji emitujących pola elektromagnetyczne. Zgodnie z art. 10 i art. 53 P.o.s., w brzmieniu obowiązującym do wejścia w życie ustawy o udostępnianiu informacji o środowisku, każdy w przypadkach określonych w ustawie miał prawo do uczestniczenia w postępowaniu w sprawie wydania decyzji z zakresu ochrony środowiska (art. 10 P.o.ś.) - w szczególności organ właściwy do wydania decyzji o środowiskowych uwarunkowaniach zapewniał możliwość udziału społeczeństwa w postępowaniu, w ramach którego sporządzany jest raport o oddziaływaniu przedsięwzięcia na środowisko (art. 53 P.o.ś.). Zważając na obowiązujące od 2002 r. kryteria kwalifikacji instalacji emitujących pola elektromagnetyczne, w większości przypadków postępowanie poprzedzające zgodę na lokalizację lub realizację stacji bazowych telefonii komórkowych przeprowadzane było z udziałem społeczeństwa (wiązało się to $\mathrm{z}$ obowiązkiem sporządzenia raportu). Dzięki temu zainteresowana społeczność uzyskiwała informację o planowanej inwestycji oraz mogła uzyskać dostęp do opracowania inwestora określającego zakres oddziaływań elektromagnetycznych na danym obszarze - w szczególności obszarze zamieszka-

20 Szerzej zob. P. Korzeniowski, [w:] M. Górski (red.) i inni, Prawo ochrony środowiska, Warszawa 2009, s. 69. 
nia. Zapewniało to wysoki poziom społecznej kontroli, jaka jest pożądana zwłaszcza w przypadkach przedsięwzięć, które przy przekroczeniu dopuszczalnych norm mogą negatywnie oddziaływać na zdrowie ludzi w sposób niewidoczny i nieodczuwalny.

W wyniku dokonanej w 2007 r. nowelizacji rozporządzenia w sprawie określenia rodzajów przedsięwzięć mogących znacząco oddziaływać na środowisko faktycznie wyłączono jednak możliwość udziału społeczeństwa we wszystkich tych postępowaniach, w których stwierdzono, że środek elektryczny urządzenia lub instalacji emitującej pole elektromagnetyczne znajduje się w odległości większej niż wskazana w rozporządzeniu od miejsc dostępnych dla ludzi. W tych postępowaniach nie wymagano już bowiem przeprowadzenia oceny oddziaływania przedsięwzięcia na środowisko, a w konsekwencji zapewnienia udziału społeczeństwa w postępowaniu. Również w aktualnym stanie prawnym, w sprawach lokalizacji lub realizacji instalacji emitujących pole elektromagnetyczne, które ze względu na parametry i odległość od miejsc dostępnych dla ludzi nie zaliczają się do przedsięwzięć mogących znacząco oddziaływać na środowisko, status strony mają tylko właściciele lub użytkownicy wieczyści nieruchomości w obszarze faktycznego oddziaływania instalacji (por. art. 28 K.p.a. ${ }^{21}$ i art. 28 ust. 2 Prawa budowlanego ${ }^{22}$ ).

Przyjęte przez prawodawcę założenie, iż postępowanie w sprawie środowiskowych uwarunkowań i zapewnienie w nim udziału społeczeństwa nie jest potrzebne w odniesieniu do instalacji emitujących pole elektromagnetyczne znajdujących się w znacznej odległości od miejsc dostępnych dla ludzi, jest teoretycznie do zaakceptowania. Wymagałoby jednak przyjęcia jednoznacznych wymogów, których zachowanie pozwalałoby stwierdzić - bez żadnych wątpliwości - że negatywne oddziaływanie na środowisko na skutek tej emisji w danym przypadku nie może wystąpić. Trzeba też pamiętać, że rezygnacja z żądania od inwestora decyzji o środowiskowych uwarunkowaniach w sto-

21 Ustawa z dnia 14 czerwca 1960 r. Kodeks postępowania administracyjnego, t.j. Dz.U. z 2000 r. Nr 98, poz. 1071 ze zm.; dalej cyt.: K.p.a.

22 Ustawa z dnia 7 lipca 1994 r. Prawo budowlane, t.j. Dz.U. z 2010 r. Nr 243, poz. 1623 ze zm.; dalej cyt.: Prawo budowlane. 
sunku do określonego rodzaju przedsięwzięć, które faktycznie na środowisko wpływają, powoduje, że na organ architektoniczno-budowlany spada obowiązek weryfikacji czy przedsięwzięcie spełnia wymagania ochrony środowiska (art. 35 ust. 1 pkt 1 Prawa budowlanego). Stąd też należy zapewnić jasne, przejrzyste i proste kryteria, pozwalające na rozróżnienie inwestycji mogących mieć znaczący wpływ na środowisko od pozostałych przedsięwzięć, które takiego wpływu mieć nie mogą i w odniesieniu do których nie wymaga się decyzji o środowiskowych uwarunkowaniach.

Wprowadzony w 2007 r. sposób zaliczania instalacji i urządzeń emitujących pole elektromagnetyczne do grupy przedsięwzięć mogących mieć znaczący wpływ na środowisko budzi bardzo poważne wątpliwości. Po pierwsze, regulacje rozporządzenia w sprawie określenia rodzajów przedsięwzięć mogących znacząco oddziaływać na środowisko (przeniesione następnie do aktualnego rozporządzenia z dnia 9 listopada 2010 r. w sprawie przedsięwzięć mogących znacząco oddziaływać na środowisko) wymagają wykładni; po drugie - zastosowanie przyjętych kryteriów może prowadzić do nie uznania za znacząco oddziałującego na środowisko przedsięwzięcia, które po uruchomieniu będzie mogło powodować w środowisku ludzkim nadmierne pole elektromagnetyczne $\mathrm{w}$ rozumieniu rozporządzenia $\mathrm{z}$ dnia 30 października 2003 r. w sprawie dopuszczalnych poziomów pól elektromagnetycznych w środowisku oraz sposobów sprawdzania dotrzymania tych poziomón ${ }^{23}$.

Przyjęte w rozporządzeniu kryteria kwalifikacji instalacji i urządzeń emitujących pola elektromagnetyczne o częstotliwościach od 0,03 MHz do 300000 MHz wyróżniają je ze względu na:

a) równoważną moc promieniowaną izotropowo wyznaczoną dla pojedynczej anteny;

b) występowanie miejsc dostępnych dla ludzi w określonej odległości od środka elektrycznego, wzdłuż osi głównej wiązki promieniowania tej anteny. 
Już po pobieżnej analizie powołanego wyżej kryterium można wyodrębnić dwa zwroty niejednoznaczne:

— „miejsca dostępne dla ludzi”

— „wzdłuż osi głównej wiązki promieniowania”.

\section{INTERPRETACJA POJĘCIA „MIEJSCA DOSTĘPNE DLA LUDZI"}

Określenie „miejsca dostępne dla ludzi” jest o tyle niefortunne, że trudno jest przesądzić czy chodzi o miejsca dostępne dla ludzi przy istniejącym stanie zagospodarowania czy też miejsca, które potencjalnie mogą być dostępne dla ludzi, np. przez rozbudowę obiektów na nieruchomości sąsiedniej. Dokonując interpretacji tego pojęcia należy odwołać się do rozporządzenia Ministra Środowiska z dnia 30 października 2003 r. w sprawie dopuszczalnych poziomów pól elektromagnetycznych w środowisku oraz sposobów sprawdzania dotrzymania tych poziomów $^{24}$. Takie odwołanie jest uzasadnione zważywszy, że przepisy dotyczące kwalifikacji przedsięwzięć do przeprowadzenia oceny oddziaływania na środowisko w istocie służą właśnie zachowaniu norm określających dopuszczalne poziomy tego oddziaływania. W myśl załącznika nr 2 pkt 7 i 11 rozporządzenia z 30 października 2003 r. pomiary w otoczeniu instalacji radiokomunikacyjnych, radionawigacyjnych oraz radiolokacyjnych, $\mathrm{w}$ przyjętych pionach pomiarowych, wykonuje się w punktach pomiarowych położonych na wysokościach od $0,3 \mathrm{~m}$ do $2 \mathrm{~m}$ nad powierzchnią ziemi albo nad innymi powierzchniami, na których mogą przebywać ludzie, przyjmując za wynik pomiaru maksymalny poziom pól elektromagnetycznych. Mając to na uwadze należy wyprowadzić wniosek, że skoro prawodawca w rozporządzeniu w sprawie określenia rodzajów przedsięwzięć mogących znacząco oddziaływać na środowisko (następnie w rozporządzeniu z dnia 9 listopada 2010 r. w sprawie przedsięwzięć mogących

${ }^{24}$ Dz. U. Nr 192, poz. 1883. 
znacząco oddziaływać na środowisko) rozróżnia przedsięwzięcia ze względu na oddziaływanie na „miejsca dostępne dla ludzi”, to rozumie przez te same „miejsca, w których mogą przebywać ludzie", w jakich następnie nakazuje dokonywać szczegółowych pomiarów promieniowania elektromagnetycznego.

Podobną interpretację pojęcia „miejsc dostępnych dla ludzi" prezentuje Naczelny Sąd Administracyjny. W wyroku z dnia 18 listopada 2010 r. o sygn. akt II OSK 602/09 NSA stwierdzil, że określenia odległości od środka elektrycznego anteny dokonuje się dla istniejącego stanu zagospodarowania otoczenia instalacji. Podobne wskazanie znalazło się w wyroku z dnia 6 października 2009 r. o sygn. akt II OSK 1426/09 oraz w wyroku z dnia 8 czerwca 2010 r. o sygn. akt II OSK 925/09. W ostatnim z orzeczeń NSA stanął na stanowisku, że skoro obszary pól promieniowania o poziomach wyższych niż $0,1 \mathrm{~W} / \mathrm{m}^{2}$ występują na wysokości powyższej $38 \mathrm{~m}$, a istniejące budynki mają maksymalnie 14 $\mathrm{m}$, to oznacza, że oddziaływanie następuje w sferze niedostępnej dla ludzi ${ }^{25}$. Warty jest odnotowania także wyrok z dnia 22 kwietnia 2010 r. wydany w sprawie o sygn. akt II OSK 1598/09. Sąd ten wskazał w nim, że w świetle $\S 2$ ust. 1 pkt 7 rozporządzenia w sprawie określenia rodzajów przedsięwzięć (w brzmieniu obowiązującym po nowelizacji z 2007 r.) nie znajduje uzasadnienia powoływanie się przez właściciela terenu na fakt, że promieniowanie będzie przechodzić nad nieruchomością, ograniczając tym samym prawo własności. „Skoro przepisy rozporządzenia Rady Ministrów mówią o miejscach dostępnych dla ludności, to oznacza, że celem ustawodawcy nie było rozstrzyganie sporów związanych z oddziaływaniem przedsięwzięcia na niedostępne dla ludności miejsca. Nie oznacza to, że właściciel nieruchomości, która takim promieniowaniem jest objęta, nie może dochodzić ochrony swego prawa w oparciu o inne przepisy, niż te, które mają zastosowanie w rozpoznawanej sprawie, a które mają na celu ochronę środowiska, a nie prawo własności". Na pod-

25 Identyczne stanowisko prezentuje Wojewódzki Sąd Administracyjny w Warszawie w wyroku z dnia 7 lipca 2010 r. sygn. akt VII SA/Wa 798/10, publ.: Centralna Baza Orzeczeń Sądów Administracyjnych, http://orzeczenia. nsa.gov.pl. 
stawie wyroku o sygn. akt II OSK 1598/09 można wyprowadzić wniosek, że Naczelny Sąd Administracyjny wyraźnie rozróżnia sfery: gdy chodzi o ochronę środowiska i gdy chodzi o ochronę prawa własności. Przesłanki nałożenia na inwestora obowiązku przeprowadzenia postępowania w sprawie środowiskowych uwarunkowań dla instalacji lub urządzenia emitującego pole elektromagnetyczne wystąpią, gdy miejsca dostępne dla ludzi - w istniejącym stanie zagospodarowania - znajdują się w odległościach wskazanych $\mathrm{w}$ rozporządzeniu w sprawie określenia rodzajów przedsięwzięć; natomiast ochrony przed ograniczeniem możliwości potencjalnego zagospodarowania danej nieruchomości sąsiedniej (gdy wiązka promieniowania przebiegać będzie wysoko nad zabudowaniami) jej właściciel będzie mógł dochodzić w oparciu o przepisy prawa cywilnego, ewentualnie przepisy techniczno-budowlane, jeżeli wykaże, że w danych warunkach nastąpiło ich naruszenie ${ }^{26}$.

Nie zawsze jednak w orzecznictwie zajmowano w tej kwestii jednoznaczne stanowisko. W sprawach, gdzie promieniowanie elektromagnetyczne o gęstości mocy większej niż $1 \mathrm{~W} / \mathrm{m}^{2}$ występowało na niższych wysokościach - zwłaszcza takich, które przy określonym, normalnym sposobie zagospodarowania terenu mogły być potencjalnie osiągnięte przez ludzi - sądy administracyjne uznawały, że ochrona przez promieniowaniem dotyczyć powinna także nieruchomości nad którymi wiązka promieniowania przebiegnie. W wyroku z dnia 15 października 2009 r. sygn. akt II OSK 1581/08 Naczelny Sąd Administracyjny zajmował się sprawą, w której odmówiono ustalenia środowiskowych uwarunkowań dla stacji bazowej telefonii komórkowej przyjmując, że zgodnie z obowiązującym na danym terenie planem miejscowym negatywne oddziaływanie pola elektromagnetycznego występującego w przestrzeni nad gruntem nie może naruszać granic nieruchomości innej niż ta, na terenie której jest wytwarzane i do której inwestor posiada tytuł prawny. Sprawa dotyczyła, co prawda, nie przepisów o kwalifikowaniu przedsięwzięć do przeprowadzenia oceny oddziaływania na środowisko,

26 Zob. niżej oraz przypisy 32 i 34. 
ale rozstrzygnięcia $\mathrm{w}$ ramach środowiskowych uwarunkowań, niemniej jednak wywód uzasadnienia wyroku jest warty uwagi. Naczelny Sąd Administracyjny wskazuje w nim, że ochronie przed nadmiernym promieniowaniem elektromagnetycznym podlega również właściciel (użytkownik wieczysty) nieruchomości, nad którą wiązka będzie przebiegać. Sąd podkreślił, iż społeczno-gospodarcze przeznaczenie nieruchomości wyznacza sposób, w jaki właściciel faktycznie i potencjalnie może zgodnie ze swoją wolą korzystać z przysługującej mu własności gruntu rozciągającej się na przestrzeń nad i pod jego powierzchnią (tzw. pionowy zasięg własności nieruchomości gruntowej). To zaś oznacza, że inwestor przez realizację zamierzeń inwestycyjnych na własnej nieruchomości nie może ograniczać bądź pozbawiać właścicieli nieruchomości sąsiednich możliwości korzystania z przysługującej im własności gruntu. Dotyczy to tak dotychczasowego korzystania jak i przyszłego korzystania z gruntu, oczywiście w granicach przysługującego prawa własności i obowiązującego systemu prawa.

Omawiany wyrok II OSK 1581/01 stał się inspiracją dla prezentowanego nieraz poglądu, że „przez miejsca dostępne dla ludności należy rozumieć nie tylko miejsca, w których wzniesiono już legalnie budynki z przeznaczeniem na pobyt ludzi, ale również miejsca, w których te budynki mogą być wznoszone zgodnie z wymogami obowiązujących przepisów”27. „Takim miejscem może być bowiem nie tylko już wzniesiony budynek, ale również np. teren, na którym urządzono albo ma być urządzony zgodnie miejscowym planem zagospodarowania przestrzennego, plac zabaw dla dzieci. Przez miejsca dostępne dla ludności należy zatem rozumieć nie tylko miejsca, w których wzniesiono już legalnie budynki z przeznaczeniem na pobyt ludzi, ale również miejsca, w których te budynki mogą być wznoszone zgodnie z wymogami obowiązujących przepisów"28.

27 Wyrok z dnia 27 sierpnia 2010 r. sygn. akt II SA/Rz 422/10; por. też wyrok z dnia 28 października 2010 r. sygn. akt II SA/Po 529/10, publ.: Centralna Baza Orzeczeń Sądów Administracyjnych, http://orzeczenia.nsa.gov.pl.

28 Wyrok z dnia 31 maja 2010 r. sygn. akt II OSK 719/09, publ.: Centralna Baza Orzeczeń Sądów Administracyjnych, http://orzeczenia.nsa.gov.pl. 
Autor niniejszego artykułu stoi na stanowisku, że przez „miejsca dostępne dla ludzi”, którym prawodawca posłużył się w rozporządzeniu w sprawie określenia rodzajów przedsięwzięć mogących znacząco oddziaływać na środowisko (aktualnie w rozporządzeniu z dnia 9 listopada 2010 r. w sprawie przedsięwzięć mogących znacząco oddziaływać na środowisko), należy rozumieć miejsca dostępne dla ludzi przy stanie zagospodarowania terenu istniejącym w dniu kwalifikowania przedsięwzięcia emitującego promieniowanie elektromagnetyczne, w przestrzeni od $0,3 \mathrm{~m}$ do $2 \mathrm{~m}$ nad powierzchnią ziemi albo nad innymi powierzchniami, na których w normalnych warunkach mogą przebywać ludzie ${ }^{29}$. Jeżeli ustalone zostanie, że tak rozumiane „miejsca dostępne dla ludzi” znajdują się w (wzdłuż) osi głównej wiązki promieniowania anten, inwestor obowiązany będzie uzyskać decyzję o środowiskowych uwarunkowaniach; z kolei, jeśli w danym stanie zagospodarowania „miejsca dostępne dla ludzi" nie znajdą się w (wzdłuż) tej osi, inwestor będzie z tego

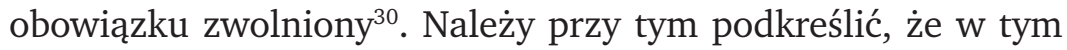
drugim przypadku organy odpowiedzialne za wydanie zezwolenia na inwestycję obowiązane będą dołożyć szczególnej staranności w określeniu rzeczywistej skali promieniowania elektromagnetycznego instalacji lub urządzenia i zapewnić czynny udział w postępowaniu wszystkim właścicielom i użytkownikom wieczystym nieruchomości znajdujących się w obszarze oddziaływania inwestycji, których interes prawny oparty będzie

29 Stosownie do Załącznika nr 2 pkt 7 i 11 rozporządzenia Ministra Środowiska z dnia 30 października 2003 r. w sprawie dopuszczalnych poziomów pól elektromagnetycznych w środowisku oraz sposobów sprawdzania dotrzymania tych poziomów.

30 Trzeba pamiętać, że przepisy rozporządzenia w sprawie określenia rodzajów przedsięwzięć mogących znacząco oddziaływać na środowisko (przeniesione następnie do aktualnego rozporządzenia z dnia 9 listopada $2010 \mathrm{r}$. w sprawie przedsięwzięć mogących znacząco oddziaływać na środowisko) służą wyłącznie ocenie czy przedsięwzięcie zalicza się do przedsięwzięć mogących znacząco oddziaływać na środowisko - zob. wyrok z dnia 22 kwietnia 2010 r. sygn. akt II OSK 1598/09, publ.: Centralna Baza Orzeczeń Sądów Administracyjnych, http://orzeczenia.nsa.gov.pl.). 
o § $314^{31}$ rozporządzenia z dnia 12 kwietnia 2002 r. w sprawie warunków technicznych, jakimi powinni odpowiadać budynki $\mathrm{i}$ ich usytuowanie ${ }^{32}$. Takie osoby muszą mieć bowiem zagwarantowaną możliwość wypowiedzenia się w sprawie i ewentualnie postawienia zarzutu, że oddziaływanie nad ich nieruchomością ogranicza im w sposób niedopuszczalny sposób jej zagospodarowania (np. gdyby wiązka przebiegała nieznacznie nad gruntem czy budynkiem ${ }^{33}$ ).

W tym miejscu należy uzupełniająco wyjaśnić, że rozporządzenia określające kryteria kwalifikacji przedsięwzięć do przeprowadzenia oceny oddziaływania na środowisko nie stanowią źródła interesu prawnego dla właścicieli nieruchomości sąsiednich, nad którymi przebiega osi głównej wiązki promieniowania elektromagnetycznego. Źródłem interesu prawnego jest dopiero rozporządzenie Ministra Środowiska z dnia 30 października 2003 r. w sprawie dopuszczalnych poziomów pól elektromagnetycznych w środowisku oraz sposobów sprawdzania dotrzymania tych poziomów ${ }^{34} \mathrm{~W}$ zW. z powołanym wyżej §314 rozporządzenia z dnia 12 kwietnia 2002 r. Stronami postępowania w sprawie dotyczącej lokalizacji albo realizacji stacji telefonii komórkowej są zatem wyłącznie właściciele nieruchomości, na które bądź nad

31 „Budynek z pomieszczeniami przeznaczonymi na pobyt ludzi nie może być wzniesiony na obszarach stref, w których występuje przekroczenie dopuszczalnego poziomu oddziaływania pola elektromagnetycznego, określonego w przepisach odrębnych dotyczących ochrony przed oddziaływaniem pól elektromagnetycznych".

32 Dz. U. Nr 75, poz. 690 ze zm.

33 Uzupełniająco trzeba dodać, że poprowadzenie wiązki elektromagnetycznej w mocy $0,1 \mathrm{~W} / \mathrm{m}^{2}$ wysoko ponad terenem - w sferze niedostępnej dla ludzi nie jest generalnie zabronione przez przepisy z zakresu ochrony środowiska i prawa budowlanego. Oczywiście właściciel nieruchomości sąsiedniej, który w przyszłości zechce zrealizować wysoki obiekt, może z tego powodu doznać ograniczeń (§314 rozporządzenia z dnia 12 kwietnia 2002 r.). Wydaje się, że w takiej sytuacji będzie on mógł żądać zaprzestania emisji pola elektromagnetycznego w oparciu o przepisy prawa cywilnego (art. 144 Kodeksu cywilnego).

34 Zob. wyrok z dnia 22 kwietnia 2010 r. sygn. akt II OSK 1598/09 oraz wyrok z dnia 17 grudnia 2010 r. sygn. akt II OSK 1917/09, publ.: Centralna Baza Orzeczeń Sądów Administracyjnych, http://orzeczenia.nsa.gov.pl. 
którymi inwestor projektuje rzeczywiste pole elektromagnetyczne wyższe niż $1 \mathrm{~W} / \mathrm{m}^{2}$.

\section{INTERPRETACJA POJĘCIA „(WZDŁUŻ) OSI GŁÓWNEJ WIĄZKI PROMIENIOWANIA"}

Od 2007 r. uzyskania decyzji o środowiskowych uwarunkowaniach wymagały instalacje emitujące pole elektromagnetyczne, jeżeli w odległościach określonych w rozporządzeniu od środka elektrycznego anteny, wzdłuż osi głównej wiązki jej promieniowania, znajdowały się miejsca dostępne dla ludzi. Termin „wzdłuż osi głównej wiązki promieniowania” już od jego wprowadzenia budził bardzo dużo kontrowersji. Trudno bowiem stwierdzić czy prawodawca miał na myśli sferę w określonej odległości od środka elektrycznego przebiegającą równolegle do osi głównej wiązki czy tylko linię wyznaczoną przez tę oś. Wątpliwości te dodatkowo spotęgowały wydane przez Ministerstwo Środowiska „Wyjaśnienia do rozporządzenia Rady Ministrów z dnia 21 sierpnia 2007 r. zmieniającego rozporządzenie w sprawie określenia rodzajów przedsięwzięć mogących znacząco oddziaływać na środowisko oraz szczegółowych uwarunkowań związanych z kwalifikowaniem przedsięwzięcia do sporządzenia raportu o oddziaływaniu na środowisko (Dz. U. Nr 158, poz. 1105)"35. Ministerstwo stwierdziło bowiem, że „oś wiązki głównej promieniowania anteny” stanowi „linię poprowadzoną wzdłuż kierunku wiązki głównej promieniowania anteny". Jed-

35 I. Mazur (Dyrektor Departamentu Ocen Oddziaływania na Środowisko Ministerstwa Środowiska) „Wyjaśnienia do rozporządzenia Rady Ministrów z dnia 21 sierpnia 2007 r. zmieniającego rozporządzenie w sprawie określenia rodzajów przedsięwzięć mogących znacząco oddziaływać na środowisko oraz szczegółowych uwarunkowań związanych z kwalifikowaniem przedsięwzięcia do sporządzenia raportu o oddziaływaniu na środowisko (Dz. U. Nr 158, poz. 1105)" - opublikowane na witrynie internetowej Ministerstwa Środowiska - http://www.mos.gov.pl/g2/big/ 2009_05/74994e3ab3b7e0ec7431235a4c1bbb0f.pdf 
nocześnie w części graficznej „Wyjaśnień” wskazało, że należy badać czy miejsca dostępne dla ludzi znajdują się w tej osi.

W orzecznictwie sądów administracyjnych interpretacja przepisów dotyczących kwalifikacji przedsięwzięć powodujących emisję pola elektromagnetycznego prezentowana przez Ministerstwo Ochrony Środowiska nie została w pełni zaakceptowana. W wyrokach dostrzeżono, że w przepisach jest mowa nie tyle o „osi” głównej promieniowania anteny, ale o pewnej sferze „wzdłuż” osi głównej. Warto zwrócić uwagę na wyrok Wojewódzkiego Sądu Administracyjnego w Bydgoszczy z dnia 4 sierpnia 2010 r. sygn. akt II SA/Bd 446/10 ${ }^{36}$. Sąd ten stwierdził, że przy badaniu czy miejsca dostępne dla ludności znajdują się w odległościach określonych w $\S 2$ ust. 1 pkt 7 i $\S 3$ ust. 1 pkt 8 rozporządzenia - nie można ograniczyć się tylko do badania przestrzeni, która jest $\mathrm{w}$ istocie „na osi” promieniowania. Podkreślił, że wskazane przepisy stanowią bowiem o miejscach dostępnych „wzdłuż” a nie „na osi” głównej wiązki promieniowania, wyjaśniając, iż pojęcie „wzdłuż” oznacza zarówno „równolegle do czegoś rozciągniętego na długiej przestrzeni, w kierunku, w którym się rozciąga” jak i „na całej długości, przez całą długość czegoś". Podobne stanowisko zajął Wojewódzki Sąd Administracyjny w Poznaniu w wyroku z dnia 2 marca 2011 r. o sygn. akt II SA/Po 785/1037. W motywach rozstrzygnięcia wskazał na konieczność interpretacji pojęcia „wzdłuż osi głównej wiązki promieniowania anteny" podkreślając, że z przedstawionej przez inwestora charakterystyki działania planowanych anten wynika, iż zasięg ich działania będzie mieścił się określonym przedziale pionowym i poziomym, a więc w przestrzeni.

Zdaniem autora niniejszego artykułu stanowisko wyrażone w ostatnim ze wskazanych orzeczeń należy w pełni podzielić. Sąd odniósł się w nim bowiem do istoty kryterium kwalifikacji instalacji emitujących pole elektromagnetyczne. Podkreślić trzeba, że rozkłady natężeń pól elektromagnetycznych w otoczeniu

36 Wyrok Wojewódzkiego Sądu Administracyjnego w Bydgoszczy z dnia 4 sierpnia 2010 r. sygn. akt II SA/Bd 446/10, publ.: Centralna Baza Orzeczeń Sądów Administracyjnych, http://orzeczenia.nsa.gov.pl.

37 Niepubl. 
instalacji radiokomunikacyjnych zależą przede wszystkim od dwóch czynników:

- charakterystyk promieniowania anten wykorzystywanych $\mathrm{w}$ instalacjach oraz

- od mocy doprowadzanych do anten ${ }^{38}$.

Nie budzi aktualnie wątpliwości, iż pole elektromagnetyczne powodowane przez instalacje i urządzenia radiokomunikacyjne ma postać wiązki, która nie jest linią, ale pewnym wycinkiem przestrzeni ${ }^{39}$. To z kolei oznacza, że potencjalne niebezpieczeństwo negatywnego oddziaływania na środowisko stacji bazowej telefonii komórkowej zachodzi nie tyle w teoretycznie wyodrębnionej „osi” (będącej prostą) co w określonej przestrzeni „wzdłuż” tej osi. Przestrzeni tej nie należy oczywiście wyznaczać dowolnie, w szczególności utożsamiać ją z całą przestrzenią łączącą oś wiązki promieniowania z poziomem terenu ${ }^{40}$. Powinna być ona określana z uwzględnieniem charakterystyk danego nadajnika (szerokości wiązki w pionie i poziomie - podanych w specyfikacji danej instalacji czy urządzenia).

Zdaniem autora niniejszego artykułu zaprezentowana w omówionych wyżej wyrokach II SA/Bd 446/10 oraz II SA/Po 785/10 wykładnia przepisów konstytuujących kryte-

38 Uzasadnienie projektu rozporządzenia z dnia 21 sierpnia 2007 r. zmieniającego rozporządzenie w sprawie określenia rodzajów przedsięwzięć mogących znacząco oddziaływać na środowisko publ. http://ww.mos.gov.pl/ bip/ pliki_do_pobrania/ 070829_1513301593projekt_29.08.pdf; zob. również Stanowisko Komisji Higieny Radiacyjnej Rady Sanitarno-Epidemiologicznej patrz. przyp. 2.

39 Tak: „Wyjaśnienia...” zob. przypis 35.

40 Trzeba zaznaczyć, że w niektórych orzeczeniach sądów administracyjnych przyjmowano niekiedy daleko idące stanowisko, iż należy badać czy miejsca dostępne dla ludzi (zabudowania) znajdują się pod osią główną wiązki promieniowania anteny - tak: wyrok z dnia 3 czerwca 2009 r. II SA/Bd 265/09 oraz wyrok z dnia 17 sierpnia 2008 r. sygn. akt IV SA/Wa 985/08. Takiej rozszerzającej wykładni kryterium kwalifikowania instalacji emitujących pole elektromagnetyczne ostatecznie nie zaakceptował Naczelny Sad Administracyjny, który w wyroku z dnia 12 lutego 2010 r. sygn. akt II OSK 297/09 uchylił orzeczenie IV SA/Wa 985/08. Przeciwko przyjmowaniu nadmiernie rozszerzającej wykładni pojęcia „wzdłuż osi głównej wiązki promieniowania” wypowiedział się także sąd w wyroku z dnia 21 kwietnia 2009 r. sygn. akt II SA/Po 1088/09. 
ria zaliczania instalacji emitujących pola elektromagnetyczne do przedsięwzięć mogących znacząco oddziaływać na środowisko zasługiwała na aprobatę. Przyjmując, że uzyskanie decyzji o środowiskowych uwarunkowaniach jest potrzebne w każdym przypadku, gdy miejsca faktycznie dostępne dla ludzi znajdują się w przestrzeni „wzdłuż” osi głównej wiązki promieniowania wyznaczonej charakterystyką emisji nadajnika pozwoliłoby zweryfikować - już na etapie planowania przedsięwzięcia - czy w miejsca te nie zostaną objęte nadmiernym promieniowaniem.

Niestety omawianego wyżej dorobku orzecznictwa nie będzie można wykorzystać w praktyce w nowych sprawach. Należy bowiem zauważyć, że w nowym i aktualnie obowiązującym rozporządzeniu z dnia 9 listopada 2010 r. w sprawie przedsięwzięć mogących znacząco oddziaływać na środowisko ${ }^{41}$ zabrakło zwrotu „wzdłuż” - odnoszącego się do lokalizacji miejsc dostępnych dla ludzi wedle osi głównej wiązki promieniowania instalacji emitujących pole elektromagnetyczne.

W myśl §2 ust. 1 pkt 7 tego rozporządzenia do przedsięwzięć mogących zawsze znacząco oddziaływać na środowisko zalicza się instalacje radiokomunikacyjne, radionawigacyjne i radiolokacyjne, z wyłączeniem radiolinii, emitujące pola elektromagnetyczne o częstotliwościach od 0,03 MHz do 300000 $\mathrm{MHz}$, w których równoważna moc promieniowana izotropowo wyznaczona dla pojedynczej anteny wynosi nie mniej niż:

a) $2000 \mathrm{~W}$, a miejsca dostępne dla ludności znajdują się w odległości nie większej niż 100 m od środka elektrycznego, w osi głównej wiązki promieniowania tej anteny,

b) $5000 \mathrm{~W}$, a miejsca dostępne dla ludności znajdują się w odległości nie większej niż 150 m od środka elektrycznego, w osi głównej wiązki promieniowania tej anteny,

c) $10000 \mathrm{~W}$, a miejsca dostępne dla ludności znajdują się w odległości nie większej niż 200 m od środka elektrycznego, w osi głównej wiązki promieniowania tej anteny,

d) $20000 \mathrm{~W}$ 
- przy czym równoważną moc promieniowaną izotropowo wyznacza się dla pojedynczej anteny także w przypadku, gdy na terenie tego samego zakładu lub obiektu znajduje się realizowana lub zrealizowana inna instalacja radiokomunikacyjna, radionawigacyjna lub radiolokacyjna. Natomiast zgodnie z $\S 3$ ust. 1 pkt 8 obowiązującego rozporządzenia do przedsięwzięć mogących potencjalnie znacząco oddziaływać na środowisko zalicza się instalacje radiokomunikacyjne, radionawigacyjne i radiolokacyjne, inne niż wymienione w $\S 2$ ust. 1 pkt 7, z wyłączeniem radiolinii, emitujące pola elektromagnetyczne o częstotliwościach od 0,03 MHz do $300000 \mathrm{MHz}$, w których równoważna moc promieniowana izotropowo wyznaczona dla pojedynczej anteny wynosi nie mniej niż:

a) $15 \mathrm{~W}$, a miejsca dostępne dla ludności znajdują się w odległości nie większej niż 5 m od środka elektrycznego, w osi głównej wiązki promieniowania tej anteny,

b) $100 \mathrm{~W}$, a miejsca dostępne dla ludności znajdują się w odległości nie większej niż 20 m od środka elektrycznego, w osi głównej wiązki promieniowania tej anteny,

c) $500 \mathrm{~W}$, a miejsca dostępne dla ludności znajdują się w odległości nie większej niż 40 m od środka elektrycznego, w osi głównej wiązki promieniowania tej anteny,

d) $1000 \mathrm{~W}$, a miejsca dostępne dla ludności znajdują się w odległości nie większej niż 70 m od środka elektrycznego, w osi głównej wiązki promieniowania tej anteny,

e) $2000 \mathrm{~W}$, a miejsca dostępne dla ludności znajdują się w odległości nie większej niż $150 \mathrm{~m}$ i nie mniejszej niż $100 \mathrm{~m}$ od środka elektrycznego, w osi głównej wiązki promieniowania tej anteny,

f) $5000 \mathrm{~W}$, a miejsca dostępne dla ludności znajdują się w odległości nie większej niż $200 \mathrm{~m}$ i nie mniejszej niż $150 \mathrm{~m}$ od środka elektrycznego, w osi głównej wiązki promieniowania tej anteny,

g) $10000 \mathrm{~W}$, a miejsca dostępne dla ludności znajdują się w odległości nie większej niż 300 m i nie mniejszej niż 200 m od środka elektrycznego, w osi głównej wiązki promieniowania tej anteny 
- przy czym równoważną moc promieniowaną izotropowo wyznacza się dla pojedynczej anteny także w przypadku, gdy na terenie tego samego zakładu lub obiektu znajduje się realizowana lub zrealizowana inna instalacja radiokomunikacyjna, radionawigacyjna lub radiolokacyjna.

Mając na względzie powyższe, z woli prawodawcy inwestor jest obowiązany uzyskać decyzję o środowiskowych uwarunkowaniach tylko w odniesieniu do instalacji lub urządzeń emitujących pole elektromagnetyczne, jeżeli miejsca dostępne dla ludzi znajdą się w odległościach wskazanych w rozporządzeniu i w linii prostej biegnącej od nadajnika w osi jego wiązki. W uzasadnieniu projektu rozporządzenia ${ }^{42}$ wskazano, że ze względu na konieczność „doprecyzowania i uniemożliwienia dowolnej interpretacji przepisu” zamieniono wyraz „wzdłuż osi głównej wiązki promieniowania...” na wyraz „w osi głównej wiązki promieniowania...".

Zmiana sposobu określenia kryteriów zaliczenia instalacji lub urządzeń emitujących pole elektromagnetyczne do kategorii przedsięwzięć mogących znacząco oddziaływać na środowisko jest kolejną - po nowelizacji tych kryteriów z 2007 r. - zmianą ograniczającą ilość przedsięwzięć, które będą objęte postępowaniem w sprawie środowiskowych uwarunkowań. Wydaje się, że jest ona zbyt daleko idąca.

Istotą oceny oddziaływania przedsięwzięcia na środowisko jest weryfikacja wymogów ochrony środowiska w odniesieniu do przedsięwzięć, które mogą znacząco oddziaływać na środowisko, a zwłaszcza zapobieżenie powstawaniu tych, które mogą mieć na nie negatywny wpływ. W przypadku instalacji lub urządzeń emitujących pole elektromagnetyczne celem nałożenia na inwestora obowiązku uzyskania decyzji o środowiskowych uwarunkowaniach jest dokonanie wstępnej i wnikliwej oceny oddziaływania tego pola na miejsca dostępne dla ludzi, a w szczególności wykluczenie sytuacji, w której w miejscach tych osiągnie ono poziom większy niż $1 \mathrm{~W} / \mathrm{m}^{2}$. Ocenie środowiskowej należy poddać zatem wszystkie instalacje lub urządzenia realizowane

42 Uzasadnienie projektu w wersji z dnia 28 września 2010 r. dostępne na witrynie internetowej Ministerstwa Środowiska: www.mos.gov.pl. 
w miejscach, gdzie takie zagrożenie występuje. Tymczasem kryterium przyjęte w rozporządzeniu z dnia 9 października $2010 \mathrm{r}$. - to jest kryterium występowania miejsc dostępnych dla ludzi „W osi" wiązki głównej promieniowania elektromagnetycznego anteny - nie gwarantuje, iż wszystkie, potencjalnie niebezpiecznie oddziałujące na środowisko ludzkie instalacje i urządzenia, będą zweryfikowane $\mathrm{w}$ postępowaniu $\mathrm{w}$ sprawie środowiskowych uwarunkowań. Przyjęte kryterium pomija bowiem sytuacje, gdy miejsca dostępne dla ludzi znajdą się we wiązce (rozumianej jako pewna przestrzeń, pole), którą projektowana antena ma emitować, jednakże obok osi tej wiązki (rozumianej jako linia prosta poprowadzona zgodnie z kierunkiem wiązki). Tego rodzaju sytuacje - z uwagi na rozmieszczanie instalacji telefonii komórkowej w gęstej zabudowie miejskiej - mogą się w praktyce zdarzać często ${ }^{43}$.

\section{KUMULACJA ODDZIAEYWAŃ INSTALACJI EMITUJĄCYCH POLA ELEKTROMAGNETYCZNE}

Kolejnym zagadnieniem rozpatrywanym przez sądy administracyjne w kontekście inwestycji stacji bazowych telefonii komórkowych była kwestia możliwej kumulacji oddziaływań. Okoliczność, iż może dojść do sumowania promieniowania elektromagnetycznego była zwykle podnoszona przez skarżących albo organizacje ekologiczne uczestniczące $\mathrm{w}$ postępowaniu sądowoadministracyjnym ${ }^{44}$. Niekiedy też zwracały na nią uwagę

43 Np. w wyrokiem z dnia 28 października 2010 r. sygn. akt II SA/Po 529/10 (publ.: Centralna Baza Orzeczeń Sądów Administracyjnych, http://orzeczenia. nsa.gov.pl). Sąd uchylił zaskarżoną decyzję z uwagi na konieczność zbadania możliwości oddziaływania promieniowania elektromagnetycznego przez wiązki przebiegające zaledwie 3,1 metra od budynków mieszkalnych.

44 Zob. wyrok z dnia 22 kwietnia 2010 r. sygn. akt II OSK 1598/09, publ.: Centralna Baza Orzeczeń Sądów Administracyjnych, http://orzeczenia.nsa. gov.pl. 
sądy w kierowanych do organów wskazaniach dotyczących konieczności uzupełnienia postępowania dowodowego ${ }^{45}$.

Kontrowersje czy w przypadku instalacji emitujących pola elektromagnetyczne należy uwzględniać sumowanie się oddziaływań powstały w kontekście $\S 2$ ust. 1 pkt 7 i $\S 3$ ust. 1 pkt 8 rozporządzenia $\mathrm{z}$ dnia 9 listopada $2004 \mathrm{r}$. (w brzmieniu po nowelizacji z 2007 r.) interpretowanego w związku z §4 rozporządzenia. W myśl powołanego §4 „parametry tego samego rodzaju, charakteryzujące skalę przedsięwzięcia i odnoszące się do przedsięwzięć tego samego rodzaju położonych na terenie jednego zakładu lub obiektu, istniejących i planowanych, sumuje się". Jednocześnie jednak $\S 2$ ust. 1 pkt 7 i $\S 3$ ust. 1 pkt 8 stanowiły o równoważnej mocy promieniowana izotropowo wyznaczonej „dla pojedynczej anteny”, a nie dla całej instalacji (jak jest np. w przypadku przedsięwzięć wymienionych w $\S 3$ ust. 1 pkt 16 lub 21 rozporządzenia z 2004 r.). Właśnie owo ograniczenie powoduje trudności z zastosowaniem §4 rozporządzenia w stosunku do instalacji emitujących pola elektromagnetyczne. Wynika to z faktu, że kryterium określone „dla pojedynczej anteny” nie daje się w istocie sumować ${ }^{46}$. Skoro bowiem odległość środka elektrycznego od miejsc dostępnych dla ludzi zależy od mocy każdej anteny osobno („pojedynczej”), to oznacza, że będzie ona taka sama, nawet w sytuacji gdy na jednym obiekcie znajdzie się kilka anten $^{47}$.

45 Zob. wyrok z dnia 26 czerwca 2010 r. sygn. akt II OSK 70/09, publ.: Centralna Baza Orzeczeń Sądów Administracyjnych, http://orzeczenia.nsa.gov.pl.

${ }_{46}$ Autor w tym miejscu podkreśla konieczność odróżnienia kryteriów określonych w rozporządzeniu dla zakwalifikowania instalacji do przedsięwzięć mogących znacząco oddziaływać na środowisko (które mają jedynie charakter pewnego z góry ustalonego poziomu - kryterium) od rzeczywistego promieniowania danej instalacji.

47 Np. gdy na jednym obiekcie znajdą się trzy nadajniki o mocy $500 \mathrm{~W}$, to nie oznacza to, że należy badać czy miejsca dostępne dla ludzi znajdują się w odległości właściwej dla mocy $1500 \mathrm{~W}$ (nie większej niż 70 m od środka elektrycznego). Przepisy stanowią o mocy promieniowanej izotropowo dla pojedynczej anteny - a więc należy badać czy miejsca dostępne dla ludzi znajdują się w (wzdłuż) osi wiązek konkretnych nadajników i w odległości zależnej od ich mocy (w podanym tu przykładzie $40 \mathrm{~m}-500 \mathrm{~W}$ ). 
Mając to na uwadze, zdaniem autora tego artykułu należy opowiedzieć się za stanowiskiem, iż do kryteriów kwalifikowania instalacji emitujących pola elektromagnetyczne $\S 4$ rozporządzenia z 2004 r. (w brzmieniu po nowelizacji z 2007 r.) nie ma i nie może mieć zastosowania, gdyż kryteriów tych - z uwagi na ich charakter - nie da się po prostu sumować. Naczelny Sąd Administracyjny zwrócił na to uwagę wyroku z dnia 22 kwietnia 2010 r. sygn. akt II OSK 1598/0948, gdzie wskazał, że „w świetle $\S 2$ ust. 1 pkt 7 rozporządzenia Rady Ministrów z 9 listopada 2004 r. w sprawie określenia rodzajów przedsięwzięć mogących znacząco oddziaływać na środowisko oraz szczegółowych uwarunkowań związanych z kwalifikowaniem przedsięwzięcia do sporządzenia raportu o oddziaływaniu na środowisko w brzmieniu obowiązującym od 31 sierpnia 2007 r. nie ulega wątpliwości, że chodzi o moc dla pojedynczej anteny, a nie o moc całkowitą". Podobnie wypowiedział się Wojewódzki Sąd Administracyjny w Warszawie w wyroku z dnia 24 czerwca 2010 r. sygn. akt IV SA/Wa 720/10 ${ }^{49}$ : „mając na uwadze regulację zawartą w cyt. rozporządzeniu (z 2004 r. - przyp. aut.), zarzut nieuwzględnienia istniejącego już promieniowania wywołanego pracą innej stacji bazowej telefonii komórkowej jest chybiony [...]. Stosownie [...] zarówno do $\S 2$ ust. 1 pkt 7, jak i § 3 ust. 1 pkt 8 cyt. rozporządzenia podstawą kwalifikacji przedsięwzięcia jako mogącego znacząco oddziaływać na środowisko, wymagającego sporządzenia raportu, jak i mogącego znacząco oddziaływać na środowisko, dla którego sporządzenie raportu może być wymagane jest równoważna moc promieniowana izotopowo wyznaczona dla pojedynczej anteny. Dla kwalifikacji tej nie ma więc znaczenia obecność w pobliżu innych anten".

Powyższy pogląd znajduje też potwierdzenie w przepisach najnowszego rozporządzenia z dnia 9 listopada 2010 r. w sprawie przedsięwzięć mogących znacząco oddziaływać na środowisko. W $\S 2$ ust. 1 pkt 7 i $\S 3$ ust. 1 pkt 8 tego rozporządzenia

48 publ.: Centralna Baza Orzeczeń Sądów Administracyjnych, http://orzeczenia.nsa.gov.pl.

49 publ.: Centralna Baza Orzeczeń Sądów Administracyjnych, http://orzeczenia.nsa.gov.pl. 
wyraźnie wskazano, że „równoważną moc promieniowaną izotropowo wyznacza się dla pojedynczej anteny także w przypadku, gdy na terenie tego samego zakładu lub obiektu znajduje się realizowana lub zrealizowana inna instalacja radiokomunikacyjna, radionawigacyjna lub radiolokacyjna". Te najnowsze przepisy niejako potwierdzają, że prawodawca nie znajduje innej możliwości wyznaczania równoważnej mocy promieniowanej izotropowo aniżeli odnoszącej się do każdej pojedynczej anteny, chociażby te znajdowały się na terenie jednego zakładu lub obiektu.

\section{PODSUMOWANIE}

Analiza orzecznictwa sądów administracyjnych prowadzi do wniosku, że w sprawach dotyczących ocen oddziaływania przedsięwzięć na środowisko przedmiotem sporów stają się coraz częściej zagadnienia dotyczące rozumienia i stosowania przepisów szczegółowych dotyczących kwalifikacji poszczególnych rodzajów inwestycji. Szczególnie dużo problemów wynikło na kanwie stosowania rozporządzeń określających kryteria zaliczenia instalacji emitujących pola elektromagnetyczne, a zwłaszcza stacji bazowych telefonii komórkowych, do kategorii przedsięwzięć mogących znacząco oddziaływać na środowisko. To wszystko zainspirowało autora niniejszego artykułu do dokonania przeglądu regulacji zawartych w tych aktach wykonawczych, analizy oraz oceny ich zmian $\mathrm{i}$ - wreszcie - przedstawienia węzłowych problemów interpretacyjnych. Artykuł ukazuje złożoność problematyki związanej z kwalifikowaniem instalacji radiokomunikacyjnych do przeprowadzenia postępowania w sprawie środowiskowych uwarunkowań. Zdaniem autora opracowanie podjętego tematu może okazać się przydatne tym bardziej, że przepisy szczegółowe określające kryteria zaliczania przedsięwzięć do kategorii przedsięwzięć mogących znacząco oddziaływać na środowisko wymagają wykładni. Wyniki tej wykładni - jak pokazują przykłady zawarte w artykule - mogą decydować o nałożeniu na inwestora stacji bazowych telefonii komórkowych obowiązku przeprowa- 
dzenia postępowania w sprawie środowiskowych uwarunkowań bądź o zwolnieniu go z niego.

\section{BIBLIOGRAFIA}

Górski M. (red.) i inni, Prawo ochrony środowiska, Warszawa 2009.

Górski M., Ochrona środowiska jako zadanie administracji publicznej, Łódź 1992.

Kontakt: j.szuma@gmail.com 